\title{
This Quarterly - A Novel Decamerone
}

You may recall 'The Mask of the Red Death', which happens to be one of the more well-known pieces by Gothic thriller author Edgar Allan Poe. It tells the story of prosperous Prince Prospero, who, whilst a deadly disease known as the 'Red Death' ravages the lands and takes away the less fortunate, closes himself up in his castle-like monastery in the company of 1000 guests, trusting that his wealth and seclusion may save him and his entourage from the gruesome fate those outside the sturdy walls are compelled to face. For purposes of entertaining his guests, the Prince organises a masquerade ball. So seven rooms ranging from the East to the West of the abbey are decorated, each of them in its own particular colour from green and purple and blue, to orange and white and violet. Only the seventh of these rooms, which is located to the very West side of the abbey, is clad in black with a blood coloured light cast from its stainedglass windows. At midnight chime a masked figure resembling a victim of the Red Death enters the scene, passing through the six chambers from East to West, ending up in the black one filled with red light. As the Prince approaches the peculiar individual, he falls to the ground, dead. His guests, thereupon tearing off the stranger's mask and robe, realize that the latter possesses no body underneath; in turn they all fall victim to the Red Death themselves.

Is Edgar Allan Poe's story teaching us a lesson for our current situation? Will secluding ourselves by shutting out the more unfortunate bear the same fatal ending as that which fell upon the Prince and his entourage?

Moreover, why, one may be tempted to comment, is such a theme featuring in the editorial of a journal on European State aid law?

The simple, straightforward, and perhaps evident answer is that the current situation is creating major changes to Member States' spending and the Commission's control of it.

But there is a more subtle and, I hold, much more apt response. 'The Mask of the Red Death' shows only one form of dealing with a situation like ours. It shows the selfishness and egotism of the rich Prince, who, whilst lacking all compassion, finally cannot avoid his own destiny. Seclusion, however, does not need to be a sign of vice. It may moreover be a sign of happiness and coping with unusual circumstances. The latter is well reflected by the one hundred short stories that Boccaccio filled his Decamerone with. They are told by a small group of young people who flee - whilst the pestilence ravages Tuscany - to a large villa outside Florence, entertaining themselves by joyful stories all centred around love, adultery, etc, with each one of them finding their own happy ending.

I would wish that this Quarterly could play the role of a special Decamerone for this community it is dedicated to and whose members cannot meet in these particular times. However, entertaining articles will keep it and us going. Let us hope we do not need one hundred of them before we can see each other again.

But bear in mind: This Quarterly's colour is green, not red. And, even in Edgar Allan Poe's short story, the green room was located to the very East, which is where the sun rises and life commences.

Andreas Bartosch 